\title{
HIF-2alpha Inhibitor PT2385
}

National Cancer Institute

\section{Source}

National Cancer Institute. HIF-2alpha Inhibitor PT2385. NCI Thesaurus. Code C119618.

An orally active, small molecule inhibitor of hypoxia inducible factor (HIF)-2alpha, with potential antineoplastic activity. Upon oral administration, HIF-2alpha inhibitor PT 2385 allosterically binds to HIF-2alpha, thereby preventing HIF-2alpha heterodimerization and its subsequent binding to DNA. This results in decreased transcription and expression of HIF-2alpha downstream target genes, many of which regulate tumor cell growth and survival. Blocking HIF-2alpha reduces the proliferation of HIF-2alpha-expressing tumor cells. HIF-2alpha, a heterodimeric transcription factor overexpressed in many cancers, promotes tumorigenesis. 